JE EXTÁZE BEZPEČNOU DROGOU?

Is ecstasy a dangerous drug?

8: 1 - 200, 2006

ISSN $1212-4117$

\title{
Polák Robert
}

Jihočeská univerzita České Budějovice, Zdravotně sociální fakulta, katedra radiologie a toxikologie

\section{Summary}

Ecstasy, MDMA (3,4-methylenedioxymetamphetamine) is a synthetic, psychoactive substance, chemically similar to the stimulant metamphetamine and hallucinogen mescaline. MDMA exerts its effects particularly in the brain or in neurons, which use serotonin for their communication with other neurons. The serotonin system plays an important role in the control of the mood, aggressivity, sexual activity, sleep and sensitivity to the pain. The research on animals demonstrated that MDMA exerts neurotoxic effects; the question, if this also holds for man is currently being intensively studied. MDMA can be dangerous and it also can rarely cause the death. In high doses, MDMA disturbs the ability of the organism to control the body temperature. This can lead to a rapid increase in the body temperature (hyperthermia) with subsequent failures of the liver, kidney and cardiovascular systems. Thus, consumers of MDMA face the same danger as consumers of other stimulants, such as cocaine or amphetamines. They increase the heart frequency and blood pressure, which can be dangerous particularly for persons with circulation problems and myocardium diseases and they also induce further symptoms, such as muscular tone, twitching of teeth, vomiting, blurred vision, faints, tremor and sweating.

Key words: Ecstasy - MDMA - metamphetamine - stimulant - hyperthemia - risk

\section{Souhrn}

Extáze, MDMA (3,4-methylendioxymetamfetamin) je syntetická, psychoaktivní látka, chemicky podobná stimulanciu metamfetaminu a halucinogenu meskalinu. MDMA uplatňuje svůj účinek především v mozku na neuronech, které používají ke komunikaci s jinými neurony serotonin. Serotoninový systém hraje významnou úlohu při regulaci nálady, agresivity, sexuální aktivity, spánku a citlivosti na bolest. Výzkumy na zvířatech ukazují, že MDMA má neurotoxický účinek; zda to platí také pro člověka, je v současné době intenzivně studováno. MDMA může být nebezpečná a vzácně může způsobit i smrt. Ve vysokých dávkách narušuje MDMA schopnost těla regulovat teplotu. To může vést k rychlému zvýšení tělesné teploty (hypertermie) a způsobit selhání jater, ledvin a kardiovaskulárního systému. Konzumenti MDMA tak čelí stejnému nebezpečí jako konzumenti jiných stimulancií jako je kokain nebo amfetaminy. Tyto zvyšují srdeční frekvenci a krevní tlak, což může být nebezpečné zejména pro osoby s oběhovými problémy a nemocemi srdce, a vyvolávají i další symptomy jako svalové napětí, nechtěné svírání zubo̊, nucení ke zvracení, rozmazané vidění, mdloby, třesavku a pocení.

Klíčová slova: extáze - MDMA - metamfetamin - stimulující látka - hypertermie - riziko

\section{ÚVOD}

Málokterým chemickým látkám je ve společnosti věnována taková pozornost jako drogám, jejichž zneužívání se ve většině společností stalo součástí určité kultury a nese s sebou řadu společenských, zdravotních, ekonomických a dalších problémů. Omezení ilegálního užívání drog je již léta nejdiskutabilnějším a nejkomplikovanějším politickým problémem v celém světě, Českou republiku nevyjímajíc. Drogy jsou spojeny s různou mírou rizika ztráty kontroly nad původně občasnou konzumací a s postupným vznikem závislosti, což zdaleka není jen problém veřejného zdraví, ale také problémem veřejné bezpečnosti. Mezi veřej- ností, ale zejména mezi toxikomany je rozšířeno přesvědčení, že braní některých drog je v podstatě bezpečné a nemělo by být pronásledováno. Takovou drogou je např. marihuana nebo extáze. Extáze je v ĆR zakázanou látkou, ale uživateli je považována za bezpečnou drogu (Vaněček, 1997). Je tomu tak opravdu?

\section{EXTÁZE}

Chemická látka známá pod názvem „Extáze“, 3,4methylendioxymetamfetamin (MDMA), je v současné době jednou z nejužívanějších drog mezi mladou generací. Patří do skupiny amfetaminů, tedy látek s psychostimulujícím účinkem 
(Fišerová, Páleníček, 2001). Má mnoho nejrůznějších pouličních názvů, u nás se nejčastěji setkáme s názvy jako éčko, extoška, tableta, pilule, $\mathrm{v}$ anglosaské literatuře $\mathrm{E}, \mathrm{XTC}, \mathrm{ADAM}$, pill a mnoho dalších. Na ilegálním trhu se vyskytuje nejčastěji ve formě tabletek různé barvy a velikosti s vylisovaným obrázkem. Výjimkou nebývají ani kapsle naplněné práškem. V tabletkách se vyskytuje MDMA v různých dávkách, obvykle mezi 50 - 150 mg. Do dnešní doby je známo něco přes 200 dalších derivátů amfetaminu s podobným účinkem, popisovaných především v undergroundové literatuře. Občas se lze setkat s tabletami obsahujícími i jiné psychostimulační a halucinogenní látky. Mezi nejznámější, a co se účinků týče i nejpodobnější, patří chemické analogy extáze, 3,4-methylendioxyamfetamin (MDA). Více jak $95 \%$ všech tablet extáze zajištěných na území ČR obsahovalo jako hlavní účinnou látku MDMA.

Málokteré droze je věnována taková pozornost jako extázi. Jen na českých internetových stránkách nalezených vyhledavačem Google nalezneme na klíčové slovo „extáze“ 162000 odkazů! Psát o ní se proto může zdát stejně zbytečné, jako „nošení drríví do lesa“, ale většina informací je povrchních, tendenčních a nekritických. Často je píší sami toxikomani a velká část je donekonečna opisována z málo důvěryhodných zdrojů.

\section{HISTORIE A SOUČASNOST}

Extáze je droga, která nebyla nikde $\mathrm{v}$ př́rodních zdrojích nalezena, takže ji musel někdo vyrobit. Kdo ji vyrobil a proč ji vyrobil? V době, kdy byla poprvé připravena chemická substance MDMA, nikdo nic netušil o jejích účincích a už vůbec ne o tom, že může člověka přivést do extatického stavu, který ji dal později i jméno (ecstasy = extáze, vytržení, nadšení, rozrušení, rozčilenî).

Syntézu a popis látky provedl v roce 1912 Dr. Anton Kollisch, chemik německé farmaceutické firmy Merck (viz Benzenhofer, Passie, 2006). V roce 1914 byla MDMA patentována firmou Merck jako anorektikum, nikdy ale nebyla komerčně vyráběna a $\mathrm{v}$ této indikaci používána.
V 60. až 80. byla omezeně používána $\mathrm{v}$ psychoterapii. Z počátku sedmdesátých let pocházejí první zmínky o zneužívání MDMA v USA. V osmdesátých letech se stala již velmi populární nejen v USA, ale i v Evropě. Casto byla $\mathrm{v}$ této době zmiňována tiskem jako bezpečná droga. Ve skutečnosti se již v této době objevovaly zprávy o její toxicitě a bylo popsáno i několik smrtelných prýpadů spojených s užitím MDMA. Ve Velké Británii se v roce 1977 objevila jako kontrolovaná substance blízká amfetaminu na seznamu zneužívaných látek. V USA se MDMA dostala na podobný seznam až v roce 1985 (do kategorie „schedule 1"), a to na základě průkazu neurotoxicity př́buzné sloučeniny MDA u hlodavců. Přesto má užívání extáze od osmdesátých let stále vzrůstající tendenci. Popularita extáze v současné době nadále vzrůstá a rozšiřruje se v celé společnosti.

V ĆR je MDMA zakázanou látkou od roku 1988, kdy byla uvedena ve skupině I prílohy č. 4 Seznamu psychotropních látek $\mathrm{k}$ nařízení vlády ČSR č. 192/1988 Sb., O jedech a některých jiných látkách škodlivých zdraví. Dnes patři mezi psychotropní látky ve smyslu zákona č. 167/1998 Sb. v př́loze č. 4. Nejčastěji jsou extáze a další amfetaminy užívány mladými lidmi (15-25 let) v klubech, a to hlavně na diskotékách s reprodukovanou taneční hudbou (např. „house“ a „techno“). Je proto také známa pod označením „taneční droga“ (Saunders, 1996). Na českém černém trhu je obvyklá cena jedné dávky, tj. 1 ks tablety, průměrně 180 až $350 \mathrm{Kč}$. Na americkém trhu se tato cena pohybuje mezi 10-30 USD a na německém 10-15 Euro. Výrobní cena MDMA je asi $1 \mathrm{Kč} \mathrm{za} \mathrm{tabletu} \mathrm{a} \mathrm{cena} \mathrm{jednoduchého} \mathrm{tableto-}$ vacího stroje asi 250.000,- Kč, takže návratnost vstupních investic je velmi rychlá.

\section{CHEMIE MDMA}

MDMA je látka ze skupiny derivátů fenylethylaminu. Je to bílá krystalická látka o b. t. $184{ }^{\circ} \mathrm{C}$, na vzduchu a světle stálá, dobře rozpustná ve vodě i v alkoholu. Není hygroskopická, tedy neabsorbuje vzdušnou vlhkost.

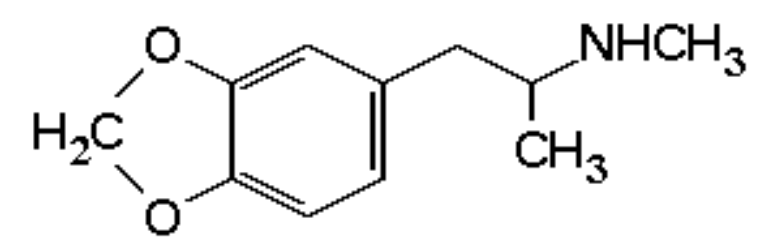




\section{FARMAKOLOGIE MDMA}

Z experimentů na zviŕatech je zřejmé, že MDMA se chová jako neurotoxin. Zasahuje do metabolismu a účinku serotoninu a katecholaminů (Miller, O’Callaghan, 1994) a tento jeho účinek je potencován stresem. Ovlivněny jsou ale i další neuromediátory, např. acetylcholin a některé hormony (ACTH, kortikosteron) a transportéry serotoninu (Vorhees et al., 2003). Neurochemické změny v mozku po podání MDMA způsobují změny chování a zvyšují agresivitu zvírat (Piper et al., 2005). U novorozených potkanů stimuluje podání MDMA expresi genu c-fos a Egr-1 v některých oblastech mozku, což vede k aktivaci D1 dopaminových receptorů (Meyer, Hsu, 2005). MDMA také zvyšuje úmrtnost novorozených potkanů (Meyer, Grande, 2002; Baltarowich et al., 2003). Také další experimenty na laboratorních zvíratech potvrzují, že MDMA vyvolává dlouhodobé a možná nevratné změny $v$ mozku, a mění tak chování zvířat (Lyles et al., 2003).

Účinky MDMA na člověka jsou mnohem méně probádány, a to zejména proto, že jen málokdy lze studovat účinek samotné extáze. V naprosté většině prípadů je její používání kombinováno s dalšími vlivy jako je pití alkoholu, kouření tabáku či marihuany, použivání jiných drog apod. Za těchto podmínek je ovšem velmi obtížné říci, která ze škodlivých látek či která jejich kombinace má za následek zdravotní problémy konzumentů MDMA (Gouzoulis-Mayfrank, Daumann, 2006). Nicméně studie posledních let jednoznačně prokazují negativní účinek MDMA na lidské zdraví. U konzumentů MDMA byla napr. prokázána jeho kardiotoxicita spojená s hypertrofií srdce (Lu et al., 2003). MDMA je potenciálně rizikovým faktorem pro průběh těhotenství a vývoj dítěte (Van Tonningen et al., 1998), i když u matek s abusem extáze nebylo pozorováno ani zvýšené množství potratů ani vrozených vad. Tomuto problému však bude nutno věnovat mnohem více pozornosti (Ho et al., 2001).

Konzumenti extáze ovšem soustavně zdůrazňují její pozitivní účinky, jako např. to, že povzbuzuje mozkovou činnost a způsobuje euforii doprovázenou pocitem uvolnění a zintenzivňuje náladu, ve které se člověk právě nachází. Tvrdí, že se cítí družnější a jsou citlivější ke svému okolí. Nepředpokládá se, že extáze může způsobovat závislost a nejsou známy žádné př́znaky spojené s odvykáním. Výzkumy ukazují, že dlouhodobá konzumace může způsobit poškození mozku a vyvolat mentální onemocnění, stejně tak jako $\mathrm{v}$ pozdějším věku problémy s játry či ledvinami. Předpokládá se, že ti, kteří mají problémy s epilepsií, vysokým krevním tlakem a depresemi, budou pravděpodobně více trpět vedlejšími příznaky (Murphy et al., 2006).

\section{NEBEZPEČÍ MDMA}

Mezi nejvážnější komplikace užívání MDMA patří hypertermie (Smolinske et al., 2003). Nebezpečí přehřátí organismu pramení z toho, že MDMA vyřazuje $z$ činnosti tepelnou regulaci organismu. Člověk ztrácí kontrolu nad pocity tepla a chladu a pokud nemá dostatečný prívod tekutin, může to vést $\mathrm{k}$ tepelnému šoku a ke kolapsu. $\mathrm{Z}$ tohoto pohledu jsou nebezpečné zejména různé taneční párty, kde se celé hodiny tancuje $\mathrm{v}$ horkém prostředí. Nebezpečné ale může být i nadměrné „preventivni““ zavodnění organismu.

Jak vyplývá z přehledu o MDMA, látka sama nezpochybnitelně představuje řadu zdravotních rizik a následných komplikací, ve většině prrípadů prímo úměrných požité dávce. Nicméně co se týče rizika úmrtí, jak potvrzují zahraniční a nakonec i naše epidemiologické statistiky, lze celkem $\mathrm{s}$ jistotou prohlásit, že na prostou otravu MDMA, tedy předávkování, zatím nikdo nezemřel. Většina úmrtí spojovaných s požitím MDMA má pravděpodobně jinou prričinu (Patel et al., 2004). Není proto ani známa letální dávka, která by zdravého člověka v běžných podmínkách dokázala usmrtit.

Hlášená úmrtí v souvislosti s MDMA souvisí s okolnostmi konzumace drogy, nevhodnými podmínkami a neočekávanými interakcemi. Spouštěčem smrtelných komplikací bývá většinou hypertermie s následnou dehydratací (Sticht et al., 2003). Na úmrtích se ale podílí také vážné úrazy a dopravní nehody. Ve většině nejzávažnějších komplikací jsou však popisovány nevhodné kombinace s jinými látkami a drogami, at' už jde o jejich současné užití, nebo o príměsi obsažené prrímo v tabletách „extáze“. Nebezpečné jsou kombinace např. s inhibitory MAO a léky interagující s isoenzymem cytochromu P450 CYP2D6 (Segura et al., 2005). Nebezpečné mohou být také kombinace s alkoholem, pervitinem nebo kokainem.

Zvláštní kapitolou jsou kombinace látek obsažené prrímo v tabletách. Provádí je sám výrobce tablet a jejich uživatel nemá tušení, že to, co polkl jako MDMA, někdy obsahuje př́měs rady jiných substancí s různými účinky. Velmi často požre místo MDMA úplně jinou látku (nebo při troše štěstí jen inertní pojiva). Je nasnadě, že zde může mnohem snáze dojít $\mathrm{k}$ neočekávaným nebezpečným účinkům, k předávkování, ke zcela neočekávaným komplikacím či nechtěným interakcím. Už z tohoto důvodu se stávají snahy o zjištění skutečného obsahu tablet „extáze“, tedy testování tablet, jednou z důležitých součástí nejrůznějších postu- 
pů a projektů zaměřených na snižování rizik souvisejících s drogami („,harm reduction“).

\section{ÚČINNÁ A SMRTELNÁ DÁVKA MDMA}

Obvyklá účinná dávka MDMA (base) bývá v rozmezí 80-150 mg. Dávky přesahující $180 \mathrm{mg}$ bývají většinou spojovány již s negativními vedlejšími účinky. Existují však případy, kdy konzumenti záměrně vyhledávají stavy související s nadměrně vysokou dávkou (více než 10 tablet najednou). Letální dávka pro MDMA není literaturou uváděna, i když jsou známy př́pady úmrtí po požití extáze v kombinaci s jinými látkami, popřípadě ve zcela specifických situacích spolu se zdravotním stavem apod. (Gable, 2004). Smrtelnou dávku je možné také odvodit z literárního údaje, který se týká MDA, kde je uváděna odhadnutá smrtelná dávka $0,5 \mathrm{~g}$ (tj. 5 tablet extáze s průměrným obsahem $100 \mathrm{mg} \mathrm{MDA}$ ) (Davis et al., 1987).

\section{ZJIŠTĚNÍ PŘÍTOMNOSTI MDMA V ORGANISMU}

U akutní intoxikace touto drogou je spolehlivou vyšetřovací metodou posouzení vzorku moči některou z citlivých metod (Sokol et al., 2005). Jestliže však $\mathrm{k}$ poslednímu užití této drogy došlo před dvěma až čtyřmi dny, pak nejsou ani mateřská substance této drogy, ani její metabolity prokazatelné v krvi, ani $\mathrm{v}$ moči. $\mathrm{V}$ těchto prŕpadech je však naprosto spolehlivá analýza vlasů, která potvrdí konzumování drogy i po několikaměsíčním odstupu od jejího užití.

\section{ZÁVĚR}

Užívání „extáze“ se nepochybně v minulých letech velmi rozšírílo a stále se rozrůstá v celé společnosti. Česká republika je v tomto ohledu téměř dramatickým př́kladem. Extáze je stále všeobecně považována za více méně bezpečnou drogu, přestože se v souvislosti s jejím užitím vyskytla i řada zdravotních fyzických i psychiatrických následných komplikací, včetně smrti. Specifické mechanismy toxicity MDMA zůstávají stále ještě ne úplně objasněné, ale je zřjejmé, že je nelze přičítat pouze předávkování MDMA nebo užívání nečistých tablet (tedy nelze svalovat toxicitu jen na príměsi v tabletách).

\section{PODĔKOVÁNÍ}

Děkuji prof. RNDr. Jiřimu Patočkovi, DrSc., za cennou pomoc při zpracování rukopisu.

\section{LITERATURA}

BALTAROWICH, L., SMOLINSKE, S., THOMAS, R.: Fatal complications of ecstasy and amphetamine abuse. $J$.
Toxicol. Clin. Toxicol. 2003. Vol. 41. s. 744.

Benzenhofer, U., Passie, T.: The early history of "Ecstasy" [Article in German] Nervenarzt. [online]. 6/2006; [Epub ahead of print]

DAVIS, W. M., HATOUM, H. T., WATERS, I. W.: Toxicity of MDA (3,4 -methylenedioxyamphetamine) considered for relevance to hazards of MDMA (Ecstasy) abuse. Alcohol Drug Res. 1987. Vol. 7, s. 123-134.

FIŠEROVÁ, M., PÁLENÍČEK, T.: MDMA (3,4methylendioxymetamfetamin) - "extáze".Adiktologie. 2001. Vol. 2, s. 61-79.

GABLE, R. S.: Acute toxic effects of club drugs. J. Psychoactive Drugs. 2004. Vol. 36, s. 303-313.

HO, E., KARIMI-TABESH, L., KOREN, G.: Characteristics of pregnant women who use Ecstasy $(3,4-$ methylenedioxymethamphetamine). Teratology. 2001. Vol. 63 , s. 280.

GOUZOULIS-MAYFRANK, E., DAUMANN, J.: The confounding problem of polydrug use in recreational ecstasy/MDMA users: a brief overview. J. Psychopharmacol. 2006. Vol. 20, s. 188-193.

LU, H. et al.: Myocardial hypertrophy in users of methylenedioxymethamphetamine MDMA. J. Toxicol. Clin. Toxicol. 2003. Vol. 41, s. 693.

LYLES, J., CAI, N. S., CADET, J. L.: Changes in gene expression induced by prenatal 3,4methylenedioxymethamphetamine (MDMA, Ecstasy) exposure. FASEB J. 2003. Vol. 17, A1213.

MEYER, J. S., GRANDE, M.: 3,4Methylenedioxymethamphetamine (MDMA) increases cell death in the neonatal rat brain. Neurotoxicol. Teratol. 2003. Vol. 24, s. 421

MEYER, J. S., HSU, A.: Induction of the immediate-early gene Egr-1 by MDMA in neonatal rats. Neurotoxicol. Teratol. 2005. Vol. 27, s. 377-378.

MILLER, D. B., O'CALLAGHAN, J. P.: Stress interactions with the neurotoxicity of the amphetamines. Neurotoxicko. Teratom. 1994. Vol.16, s. 327-328.

MURPHY, P. N., WAREING, M., FISK, J.: Users' perceptions of the risks and effects of taking ecstasy (MDMA): a questionnaire study. J. Psychopharmacol. 2006. Vol. 20, s. 447-455.

PATEL, M. M. et al.: Shedding new light on the "safe" club drug: methylenedioxymethamphetamine (ecstasy)-related fatalities. Acad. Emerg. Med. 2004. Vol. 11, s. 208-210.

PIPER, B. J. et al.: Analysis of the behavioral and neurochemical consequences of (+/-)3,4methylenedioxymethamphetamine (MDMA or "ecstasy"). Neurotoxicol. Teratol. 2005. Vol. 2 7, s. 377.

SAUNDERS, N.: Extáze a Techno scéna, 1. vyd., Brno: JOTA, 1996. s. 314.

SEGURA, M., FARRE, M., PICHINI, S. et al.: Contribution of cytochrome P450 2D6 to 3,4methylenedioxymethamphetamine disposition in humans: use of paroxetine as a metabolic inhibitor probe. Clin. Pharmacokinet. 2005. Vol. 44, s. 649-660.

SMOLINSKE, S., BALTAROWICH, L., THOMAS R.: "Ecstasy? and methamphetamine related hyperthermia. Toxicol. Clin. Toxicol. 2003. Vol. 41, s. 655.

SOKOL, M., FUSEK, J., NAVRÁTIL, P.: Omamné a psychotropní látky - metodologie profesních testů pro potřeby armády ČR. Voj. Zdrav. Listy. 2005. Vol. 74, s. 49-52.

STICHT, G., PLUISCH, F., BIERHOFF, E., KAFERSTEIN, H.: Fatal outcome of Ecstasy overdose [Article in German] Arch. Kriminol. 2003. Vol. 211, s. 73-80.

VANĚČEK, M.: Extáze. Bull. Nár. Protidrog. Centr. Praha, 1997. Vol. 1, s. 9-11.

VAN TONNINGEN, M. R., GARBIS, H., REVERS, M. 
1998: Ecstasy exposure during pregnancy. Teratology 58: $33 \mathrm{~A}$

VORHEES, C. V. et al.: Short-term effects of P11 MDMA treatment on monoamines, $\mathrm{ACTH}$, corticosterone and seroonin transporter in rats. Neurotoxicol. Teratol. 2003. Vol. 25, s. 385-386. 